\title{
HISTO-ARCHITECTURAL CHANGES OF INTESTINAL MORPHOLOGY IN ZEBRA FISH (Danio rerio) EXPOSED TO SUMITHION
}

\section{Sk. Istiaque Ahmed ${ }^{1,2}$, Mirja Kaizer Ahmmed ${ }^{2}$, Subrata Kumar Ghosh ${ }^{2}$, Md. Moudud Islam ${ }^{2}$ and Md. Shahjahan ${ }^{1 *}$}

${ }^{1}$ Department of Fisheries Management, Faculty of Fisheries, Bangladesh Agricultural University, Mymensingh-2202, Bangladesh; ${ }^{2}$ Faculty of Fisheries, Chittagong Veterinary and Animal Sciences University, Khulshi, Chittagong- 4225, Bangladesh

*Corresponding author: Dr. Md. Shahjahan; E-mail: mdshahjahan@bau.edu.bd

\section{ARTICLE INFOABSTRACT}

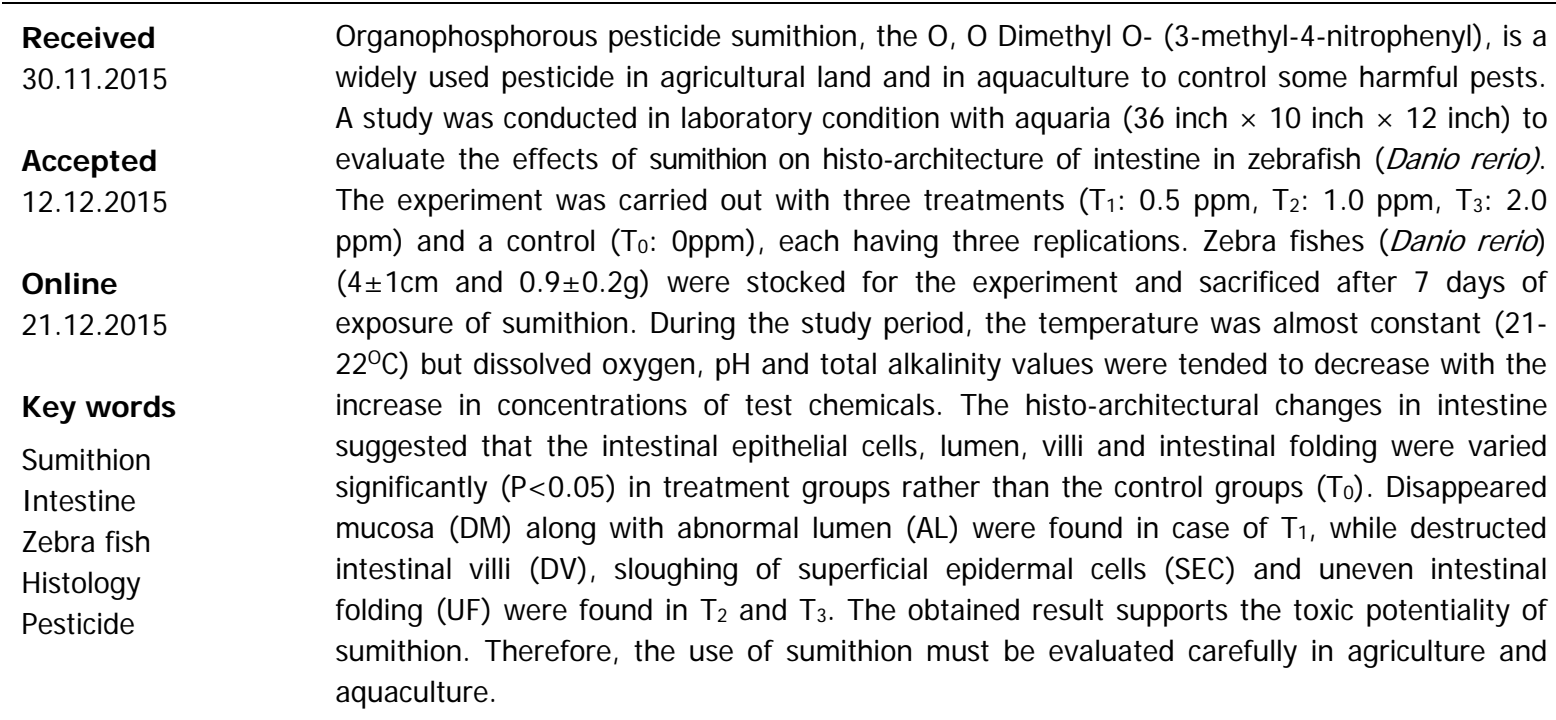

To cite this article: Ahmed S I, M K Ahmmed, S K Ghosh, M M Islam and M Shahjahan, 2015. Histo-architectural changes of intestinal morphology in Zebra fish (Danio rerio) exposed to Sumithion. Res. Agric. Livest. Fish. 2 (3): 499-506.

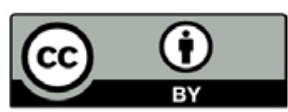

This is an open access article licensed under the terms of the Creative Commons Attribution 4.0 International License

www.agroaid-bd.org/ralf, E-mail: editor.ralf@gmail.com 


\section{INTRODUCTION}

Pesticides have been considered as a major threat of gradual degradation for the aquatic ecosystem (Salam et al., 2015; Sharmin et al., 2015). Thirty nine insecticides, under four major groups viz. organochlorine, organophosphate, carbamate and pyrethroid, are being used in agricultural and public health sector (Satter, 1985) of which over $98 \%$ of sprayed insecticides and $95 \%$ of herbicides have impacts not only upon their target species but also on non-target species, air, water, bottom sediments and food (Miller and Miller 2004; Rahman et al., 2012).

Sumithion, an organophosphate insecticide is considered somewhat toxic to fish (Thomson, 1989) but no clear evidence on the intestinal morphological alteration was found so far. Toxicology studies on different tissues (Thophon et al., 2003) can provide information about tissues injuries and damages of organs resulting in morphological dysfunction.

Being one of the most common, small and robust vertebrate model organisms, zebrafish got the highest priority to conduct this experiment (Shahjahan et al., 2013). Generally, every species possess an immense power of biotic potential in favorable condition by increasing the population to the explosive level. But, in adverse condition, different organs such as intestine, gonad etc. may be affected. Therefore, this study was carried out to determine the effect of sumithion on intestine of zebrafish.

\section{MATERIALS AND METHODS}

Proper and absolute analysis of impacts of pesticides and their contamination under field conditions is extremely difficult, but the need for field tests in this aspect can be reduced to a greater extent by the implementation of controlled laboratory tests. That is why, the present study was carried out from January to April, 2014 at the wet laboratory of the Faculty of Fisheries, Bangladesh Agricultural University (BAU), Mymensingh, Bangladesh.

\section{Species selection}

The Zebrafishes (Danio rerio) with a length of $4 \pm 1 \mathrm{~cm}$ and weight of $0.9 \pm 0.2 \mathrm{~g}$, were selected on the basis of the health condition from different ponds adjacent to academic building of Fisheries Faculty, BAU. The selected fishes were acclimatized in aquaria at $22 \pm 0.5^{\circ} \mathrm{C}$ under a controlled natural photo-regimen $(14 / 10 \mathrm{~h}$, light/dark) condition for a period of 21 days before the experiments. During acclimatization process, the fish were fed twice a day with commercial grower feed (CP Bangladesh Co., Ltd.).

\section{Experimental procedure for acute and behavioral toxicity}

According to the standard method, a static acute toxicity bioassay was performed to determine the 24,48 , 72 , and $96 \mathrm{~h}$ lethal concentration values (LC50) of sumithion for Zebra fish. Seven different concentrations (4, $5,6,7,8,9$, and $10 \mathrm{ppm}$ ) of sumithion with three replicates were used in the test series. Control units with three replicates were also prepared. Exceeding aeration was applied to the aquarium for $2 \mathrm{~h}$ in order to obtain a homogeneous concentration of the toxic compound, and then 10 fish were transferred into each aquarium. Mortality was assessed at 24, 48, 72, and $96 \mathrm{~h}$ after the start and dead fishes were removed immediately. Several behavioral changes, such as reduced activity, equilibrium imbalance, abnormal swimming and motion inactivity of the fishes were observed during the exposure period.

\section{Experimental design}

Twelve aquaria (36 inch $\times 10$ inch $\times 12$ inches) were collected, cleaned, washed and sun-dried properly prior to set in the wet laboratory. The experiment was conducted with three treatments $\left(T_{1}: 0.5 \mathrm{ppm}, \mathrm{T}_{2}: 1.0\right.$ ppm, $\left.T_{3}: 2.0 \mathrm{ppm}\right)$ and a control $\left(\mathrm{T}_{0}: 0 \mathrm{ppm}\right)$, each having three replications. Ten fish were stocked in each aquarium containing $20 \mathrm{~L}$ of tap water. Fish were sacrificed after the desired exposure of sumithion (7 days) to observe the effects on intestine. The fish sample was collected and fixed in $10 \%$ formalin for the use of histological analysis. The application of pesticide at desired concentration was reapplied at every $24 \mathrm{~h}$ with a regular exchange of water. 


\section{Feeding frequency}

The feeding frequency was 2 times per day $(9.00 \mathrm{am}$ and $9.00 \mathrm{pm})$ at a rate of $70 \%$ of their body weight throughout the experimental period. Before introducing feed for the next feeding, previous uneaten feeds and feces in aquarium were removed by siphoning using a plastic pipe.

\section{Monitoring of water quality parameters}

During the experimental period, the water quality parameters such as temperature with a thermometer, $\mathrm{pH}$ with a $\mathrm{pH}$ meter, dissolved oxygen with a DO meter and total alkalinity with hachkit were recorded.

\section{Histological study of intestine}

For histological analysis of intestine, three fish species were selected from each treatment. Then cephalic and caudal portion of the selected fishes were cut off and the intestinal section was preserved at $10 \%$ formalin. The preserved samples were taken out from vials and put into cassettes separately. Then dehydration process was carried out manually followed by clearing, infiltration, embedding, sectioning, staining and mounting. Finally, intestinal sections were observed under microscope and photographs were taken at 10x magnification.

\section{Statistical analysis}

Values were expressed as means \pm standard deviation (SD). Data were analyzed by one-way analysis of variance (ANOVA) followed by Tukey's post hoc test to assess statistically significant differences among the control and different treated values. Statistical significance was set at $P<0.05$. Statistical analyses were performed using PASW Statistics 18.0 software (IBM SPSS Statistics, IBM, Chicago, USA).

\section{RESULTS AND DISCUSSIONS}

\section{Acute and behavioral toxicity}

The mortality patterns of the test species exposed to different doses of sumithion are presented in Table 1. No mortality was observed in control treatment, whereas the mortality percentage increased as the concentration of sumithion increased. The LC50 value of zebrafish for sumithion during the $96 \mathrm{~h}$ of exposure was $7.89 \mathrm{ppm}(\approx 8)$. A series of abnormal behavior such as restlessness, sudden quick movement, rolling movements, swimming on the back (at higher doses) etc. was observed during the continuation of experiment. Due to the application of higher doses, the affected fish became extremely weak and ultimately died. No such abnormalities were observed in terms of behavior in the control group.

In the present study, the LC50 value $(7.89 \mathrm{ppm})$ recorded for $D$. rerio is less than the values $(9.14 \mathrm{ppm}$ for Ptychocheiilus lucius, $11700 \mu \mathrm{g} / \mathrm{L}$ for black bullhead, $11.8 \mathrm{ppm}$ for Heteropneustes fossilis, $15.3 \mathrm{ppm}$ for Gila elegance and 17.0 ppm for Ictalurus furcatus) determined by Durkin (2008) and Faria et al. (2010) for different fish species. In contrast to the above-mentioned values, Pathiratne and George (1998) reported a lower $96 \mathrm{~h}$ LC50 value (2.2 ppm) for Oreochromis niloticus. Newhart (2006) tabulated the LC50 values of malathion for different species of fish which ranges from 0.06 to $7620 \mu \mathrm{g} / \mathrm{L}$. Malathion was found to be highly toxic to fry of Labeo rohita (LC50 value $9 \mu \mathrm{g} / \mathrm{L}$ ), Patil and David, (2008); Opheocephalus punctatus (LC50 $16 \mu \mathrm{g} / \mathrm{L}$ ), Pugazhvendan et al., (2009); walleye (LC50 $64 \mathrm{ppb),} \mathrm{brown} \mathrm{trout} \mathrm{(LC50} 101 \mathrm{ppb}$ ) and cutthroat trout (LC50 $280 \mathrm{ppb}$ ) and moderately toxic to minnows (LC50 $8.6 \mathrm{ppm}$ ) and murrels (LC50 $5.93 \mathrm{ppm}$ ) as summarized by Durkin (2008). The difference in the potentiality of pesticides toxicity may be attributed mainly to the susceptibility of the test animals and several factors like $\mathrm{pH}$ and hardness of water. The observation of a series of abnormal behaviors such as restlessness, loss of equilibrium, increased opercular activities, surface to bottom movement, sudden quick movement, resting at the bottom, etc. were similar to the observations of Haque et al. (1993) and Lovely (1998). Some aspects that are contrary to the findings of Kabir and Begum (1978) and Lovely (1998) such as swelling in the abdominal region and gas-filled stomach were not observed.

\section{Effects of sumithion on water quality parameters}

Recording of water quality parameters (Temperature, Dissolved oxygen, $\mathrm{pH}$ and Total Alkalinity) was a regular task during the exposure period of sumithion at various concentrations as well as with control. During the study period of 7 days the values of Temperature were almost constant regardless of the application of treatments. Dissolved oxygen, $\mathrm{pH}$ and total alkalinity values were tended to decrease with the increase in concentrations of test chemicals (sumithion) (Table 2), but the values were not significantly varied $(P>0.05)$. 
Table 1. Mortality percentages of the selected fish samples exposed to different concentrations of sumithion at different time intervals.

\begin{tabular}{|c|c|c|c|c|c|c|c|}
\hline \multirow{2}{*}{ SL No. } & \multirow{2}{*}{$\begin{array}{l}\text { Concentration } \\
(\mathrm{mg} / \mathrm{L})\end{array}$} & \multirow{2}{*}{$\begin{array}{l}\text { Initial No. of } \\
\text { fish }\end{array}$} & \multicolumn{4}{|c|}{ Count of dead fish after } & \multirow{2}{*}{$\begin{array}{l}\% \text { of } \\
\text { mortality }\end{array}$} \\
\hline & & & $24 \mathrm{~h}$ & $48 \mathrm{~h}$ & $72 \mathrm{~h}$ & $96 \mathrm{~h}$ & \\
\hline 1 & Control & 10 & - & - & - & - & 00 \\
\hline 2 & 4.0 & 10 & - & - & - & 1 & 10 \\
\hline 3 & 5.0 & 10 & - & - & - & 2 & 20 \\
\hline 4 & 6.0 & 10 & - & - & 2 & 3 & 30 \\
\hline 5 & 7.0 & 10 & 1 & 2 & 3 & 4 & 40 \\
\hline 6 & 8.0 & 10 & - & 2 & 4 & 5 & 50 \\
\hline 7 & 9.0 & 10 & 1 & 3 & 7 & 9 & 90 \\
\hline 8 & 10.0 & 10 & 2 & 7 & 9 & 10 & 100 \\
\hline
\end{tabular}

Table 2. Water quality parameters (Means \pm SD) during the study period.

\begin{tabular}{|c|c|c|c|c|}
\hline \multirow{2}{*}{ Parameteres } & \multicolumn{4}{|c|}{ Treatments } \\
\hline & $\mathrm{T}_{0}$ (0 ppm) & $\mathrm{T}_{1}(0.5 \mathrm{ppm})$ & $\mathrm{T}_{2}(1.0 \mathrm{ppm})$ & $\mathrm{T}_{3}(2.0 \mathrm{ppm})$ \\
\hline Temperature $\left({ }^{\circ} \mathrm{C}\right)$ & $21.6 \pm 0.71$ & $21.48 \pm 0.34$ & $21.34 \pm 0.15$ & $22.20 \pm 0.40$ \\
\hline $\mathrm{pH}$ & $7.21 \pm 0.07$ & $6.81 \pm 0.07$ & $6.58 \pm 0.11$ & $6.40 \pm 0.13$ \\
\hline Dissolved oxygen (mg/L) & $4.62 \pm 0.12$ & $3.41 \pm 0.15$ & $3.18 \pm 0.19$ & $2.93 \pm 0.12$ \\
\hline Total Alkalinity (mg/L) & $175.71 \pm 1.38$ & $163.57 \pm 1.98$ & $159.28 \pm 6.36$ & $149.28 \pm 6.89$ \\
\hline
\end{tabular}

There have been profound significances on environmental parameters in affecting the toxicity of different pesticides. Considering the significance of temperature on different factors like enzyme activity, metabolic rate, oxygen uptake etc, it has been studied more widely than any other environmental parameters. Generally, toxicity is more or less proportionate to high temperature. Macek et al. (1969) studied the effects of 10 pesticides to the rainbow trout and 11 pesticides to the bluegills at different temperatures and found that the toxicity increased with increasing temperature. $\mathrm{P}^{\mathrm{H}}$ has also been found significant in influencing various physicochemical properties of pesticides like hydrolysis, volatilization and in balancing the dissociated and undissociated forms (Weber, 1972). The toxicity of organophosphate (OP) compounds is not influenced by $\mathrm{pH}$ very commonly except in few cases. The toxic effects of 2, 4-D were reduced when the $\mathrm{pH}$ was raised by the addition of sodium chloride (Holcombe et al., 1980). Davies (1975) attempted to formulate the criteria for minimum dissolved oxygen requirement of fish. His approach was on examining the threshold levels of dissolved oxygen that cause changes in some physiological lesions. Channel Catfish exposed for $72 \mathrm{~h}$ to an oxygen content of 1.5 ppm showed anomalies in gill, liver, kidney and spleen (Scott and Rogers, 1980). In the present investigation the variation of the different water quality parameters (Temperature, Dissolved oxygen, $\mathrm{pH}$ and Alkalinity) that were monitored during the exposure period within various concentrations of pesticides as well as with the control were not significant. The limited variations in these parameters among different treatments may be due to regular renewal of water and pesticide at every 24 hours. 


\section{Effects of sumithion on histo-architecture of intestine}

In this experiment, the histo-architecture of zebrafish intestine was observed through histology. The intestinal epithelial cells, lumen, villi and intestinal folding were almost regular in control groups ( $\left.T_{0}\right)$, while in treatments various abnormalities were found. In $T_{1}$, the intestinal mucosa was almost disappeared (DM) along with abnormal lumen (AL). On the other hand, destructed intestinal villi (DV), sloughing of superficial epidermal cells (SEC) and uneven intestinal folding (UF) were found in $\mathrm{T}_{2}$ and $\mathrm{T}_{3}$ (Figure 1). The result also indicated that the Zebra fish intestine was damaged by $20 \%, 50 \%$ and $70 \%$ in $T_{1}, T_{2}$ and $T_{3}$, respectively (Figure 2 ) and varied significantly $(P<0.05)$ among treatments.
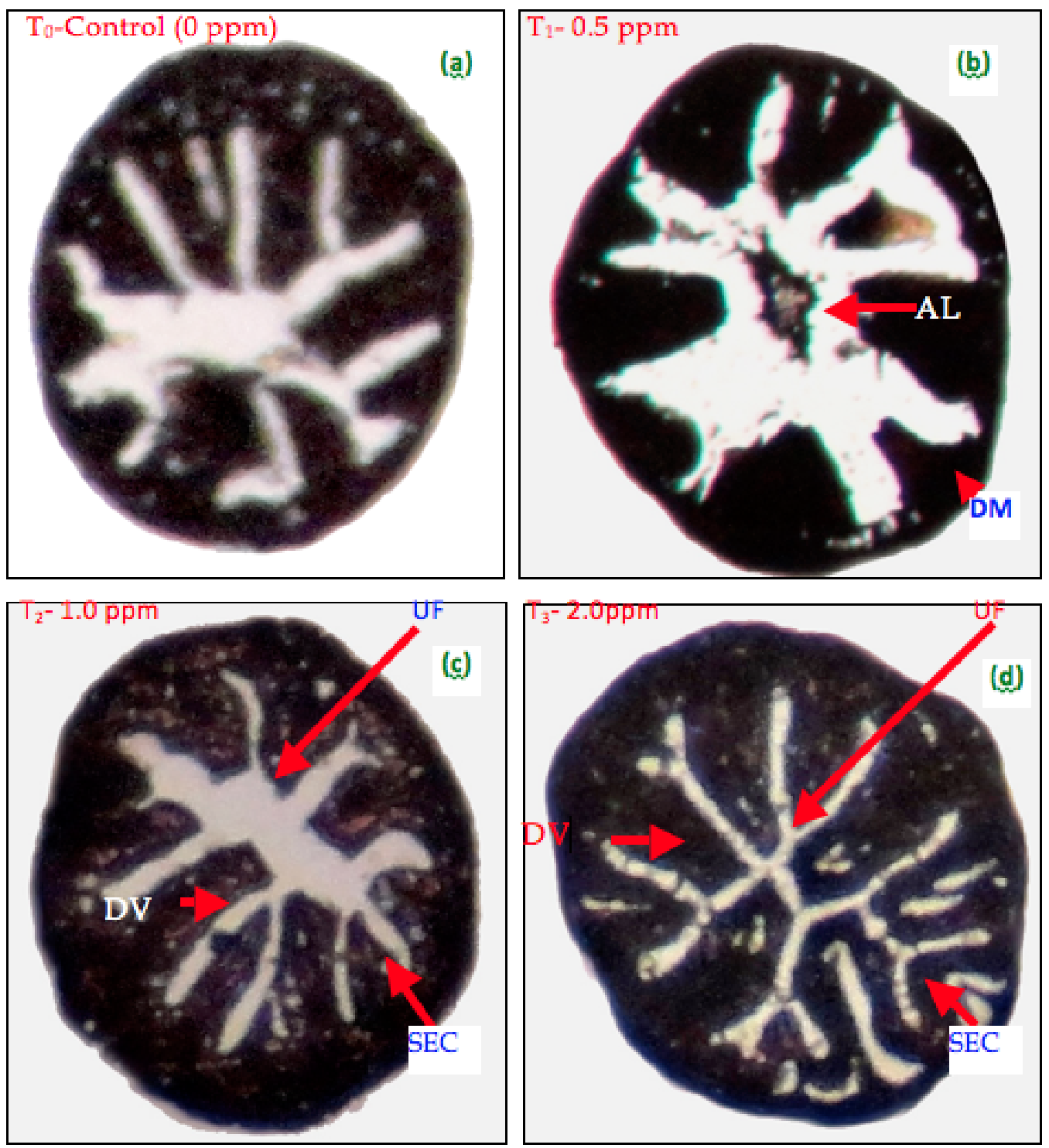

Figure 1. Histo-architectural changes in intestine exposed to sumithion; (a) Control ( $\left.T_{0}\right)$, (b) 0.5 ppm ( $\left.T_{1}\right)$, (c) 1.0 ppm $\left(\mathrm{T}_{2}\right)$ and (d) $2.0 \mathrm{ppm}\left(\mathrm{T}_{3}\right)$. Arrowheads are indicating Abnormal Lumen (AL), Disappeared Mucosa (DM), Destructed Villi (DV), Uneven intestinal Folding (UV) and Sloughing of Epithelial Cells (SEC). 


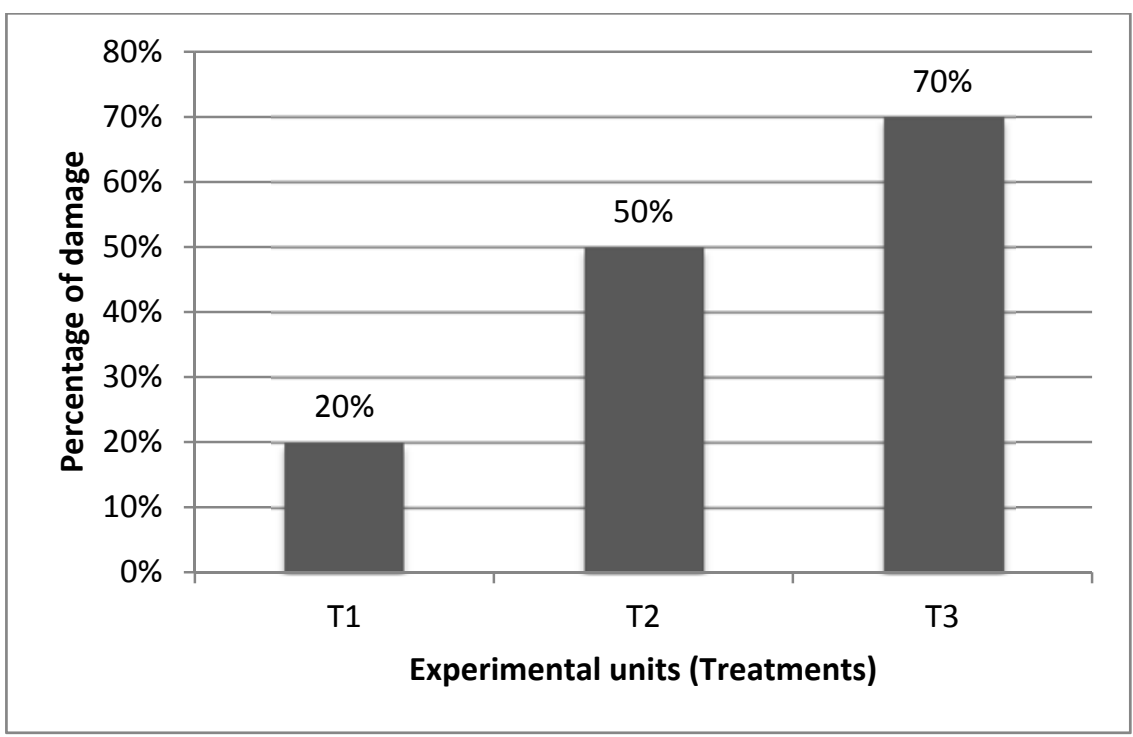

Figure 2. Percentage of damage in Zebra fish intestine due to sumithion exposure

Das and Gupta (2013) suggested a severe damage in intestinal mucosa, destructed epithelial walls, infiltration of lymphocytes and vacuolation in the intestine of Indian Flying Barb, Esomus danricus when it was exposed to malathion at $1.79,0.179$ and $0.00179 \mu \mathrm{g} / \mathrm{l}$ concentration for 28 days. Velmurugan et al. (2007) observed atrophy of epithelial cells, necrosis of epithelial cells and infiltration of lymphocytes into the lamina propia in the intestine of Cirrhinus mrigala exposed to fenvalerate. According to Desai el al. (1984), the degenerative and necrotic changes observed in the different intestinal layers of the studied fish may be due to a direct effect of the detected pesticides on the cells, to an accumulation of acetylcholine in the tissues or to a reduction in oxygen supply. According to Bhatnagar et al. (2007), the observed irritation and destruction of the mucosa membrane of the intestine hamper absorption. The pathological alterations in the intestine of the studied fish is in agreement with those observed by many investigators about the effects of different toxicants on fish intestine (Hanna et al., 2005; Cengiz and Unlu, 2006). Walsh and Ribelin (1975) reported hyperemia, degenerative changes in the tips of villi, loss of structural integrity of mucosal folds, hypertrophy vacuolation and necrosis in the intestine of Cyprinus carpio exposed to the pesticide atrazine. The present study, thus, concludes that although organophosphate pesticides are found to be less toxic to mammals than organochlorines, yet, very low doses of such pesticides (sumithion) can cause apparent damage in the intestine of fish.

\section{CONCLUSION}

The current research activity was conducted on the basis of an aim to evaluate the effects of sumithion on histo-architecture of intestine in zebrafish. It is concluded that sumithion seems to be somewhat toxic to zebrafish. The data obtained in the present experimental protocol revealed significance that sumithion has adverse effects on the intestinal arrangement of fish. In addition, the indiscriminate use of pesticide in the field may be a threat to human, fauna and flora of the environment.

\section{CONFLICT OF INTEREST}

The authors declare that they have no conflict of interests. The authors alone are responsible for the content and writing of the paper. 


\section{ACKNOWLEDGEMENTS}

This work was supported by a grant of Impact of Aquaculture Drugs and Chemicals on Aquatic Ecology and Productivity Project (IADCAEPP) provided by Bangladesh Fisheries Research Institute (BFRI), Mymensingh2201, Bangladesh.

\section{REFERENCES}

1. Bhatnagar C, Bhatnagar M and Regar B, 2007. Fluoride-induced histopathological changes in gill, kidney, and intestine of fresh water teleost, Labeo rohita. Research Report Fluoride, 40: 55-61.

2. Cengiz El and Unlu E, 2006. Sublethal effects of commercial deltamethrin on the structure of the gill, liver and gut tissues of mosquitofish, Gambusia affinis: a microscopic study. Environmental Toxicology and Pharmacology, 21: 246-253.

3. Das S and Gupta A, 2013. Histopathological changes in the intestine of Indian Flying Barb (Esomus Danricus) exposed to organophosphate pesticide, Malathion (Ec 50). Global Journal of Biology, Agriculture and Health Sciences, 2: 90-93.

4. Davies JS, 1975. Minimal dissolved oxygen requirement of aquatic life with emphasis on Canadian species: a review. Journal of Fisheries Research Board of Canada, 32: 2295-2332.

5. Desai AK, Joshi VM and Ambadkar PM, 1984. Histological observations on the liver of Tilapia mossambica after exposure to motiocrotophos, an organophosphorus insecticide. Toxicolology Letters, 21: 325-331.

6. Durkin PR, 2008. Malathion; Human Health and ecological risk assessment. Final report submitted to Paul Mistretta, PCR, USDA/Forest Service, Suthern region, Atlanta, Georgia, pp. 325.

7. Faria IR, Palumbo AJ, Fojut TL and Tjeerdema RS, 2010. Water Quality Criteria Report for Malathion. Phase III: Application of the Pesticide Water Quality Criteria Methodology. University of California, DAVIS, 7, pp. 64.

8. Hanna M, Shaheed I and Elias N, 2005. A contribution on chromium and lead toxicity in cultured Oreochromis niloticus. Egyptian Journal of Aquatic Biology and Fish, 9: 177-209.

9. Haque MM, Mirza MJA and Miah MS, 1993. Toxicity of Diazinon and Sumithion to Puntius gonionotus. Bangladesh. Journal of Training and Development, 6: 19-26.

10. Holcombe GW, Flandt JT and Phipps GL, 1980. Effect of $\mathrm{pH}$ increases and sodium chloride addition on the acute toxicity of 2-4 dichlorophenol to the fathead minnow. Water Research, 14: 1073.

11. Kabir SMH and Begum R, 1978. Toxicity of three organophosphorus insecticides to Singhi fish Heteropneustes fossilis (Bloch). Dhaka University Studies, Part B, 26: 115-122.

12. Lovely F, 1998. Toxicity of Three Commonly Used Organo-Phosphorus Insecticides to Thai Sharpunti (Barbodes gonionotus) and African Catfish (Clarias gariepinus) Fry. M.Sc. Thesis, Department of Fisheries Biology and Genetics, Bangladesh Agricultural University, Bangladesh.

13. Mckim JM, Benoit DA, Biesinger KK, Brungs WA and Siefert RE, 1975. Effects of pollution on fresh water fish. Journal of the Water Pollution Control Federation, 47: 1711-1764.

14. Miller KV and Miller JH, 2004. Forestry herbicide influences on biodiversity and wildlife habitat in southern forests. Wildlife Society Bulletin, 32: 1049-1060.

15. Newhart KL, 2006. Environmental Fate of Malathion. California Environmental protection Agency, USA, pp. 20.

16. Pathiratne A and George SG, 1998. Toxicity of malathion to Nile tilapia, Oreochromis niloticus and modulation by other environmental contaminants. Aquatic Toxicology, 43: 261-271.

17. Patil VK and David M, 2008. Behaviour and respiratory dysfunction as an index of malathion toxicity in the freshwater fish Labeo rohita (Hamilton). Turkish Journal of Fisheries and Aquatic Sciences, 8: 233237. 
18. Pugazhvendan SR, Narendiran NJ, Kumaran RG, Kumaran S and Alagappan KM, 2009. Effect of Malathion Toxicity in the Freshwater Fish Ophiocephalus punctatus-A Histological and Histochemical Study. World Journal of Fish and Marine Sciences, 1: 218-224.

19. Rahman MS, Shahjahan M, Haque MM and Khan S, 2012. Control of euglenophyte bloom and fish production enhancement using duckweed and lime. Iranian Journal of Fisheries Sciences, 11: 358-371.

20. Salam MA, Shahjahan M, Sharmin S, Haque F and Rahman MK, 2015. Effects of sub-lethal doses of an organophosphorous insecticide sumithion on some hematological parameters in common carp, Cyprinus carpio. Pakistan Journal of Zoology, 47: 1487-1491.

21. Satter MA, 1985. The use of pesticides in Bangladesh and protection of environment. Proceeding of the SAARC Seminar on Protecting the Environment from Degradation, Dhaka, Bangladesh.

22. Scott AL and Rogers WA, 1980. Histological effects of prolonged sublethal hypoxia of channel catfish, Lctalurus punctuates. Journal of Fish Diseases, 3: 305.

23. Shahjahan M, Kitahashi T, Ogawa S and Parhar IS, 2013. Temperature differentially regulates the two kisspeptin system in the brain of zebrafish. General and Comparative Endocrinology, 193: 79-85.

24. Sharmin S, Shahjahan M, Hossain MA, Haque MA and Rashid H, 2015. Histopathological Changes in Liver and Kidney of Common Carp Exposed to Sub-lethal Doses of Malathion. Pakistan Journal of Zoology, 47: 1495-1498.

25. Thomson WT, 1989. Agricultural Chemicals. Book I: Insecticides. Thomson Publications, Fresno, California. pp. 120.

26. Velmurugan B, Selvanayagam M, Cengiz E and Unlu E, 2007. The effects of fenvalerate on different tissues of freshwater fish (Cirrhinus mrigala L.). Journal of Environmental Science and Health, 42: 157163.

27. Walsh AH and Ribellin WE, 1975. The Pathology of Pesticide. In: WR Rebellin and G. Migaki (Editors), Pathology of Fishes. University of Wisconsin press, Madison. pp. 515-537.

28. Weber JB, 1972. Interaction of Organic Pesticides with Particulate Matter in Aquatic Soil system, in Fate of Organic Pesticides in the Aquatic Environment (Advances in Chemistry Series III). Faust, S.D., Eds. American Chemical Society Washington D.C. pp. 55. 